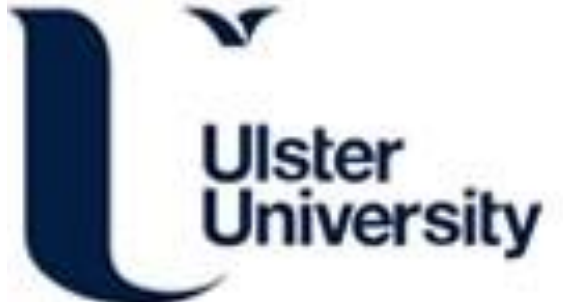

\section{Outer- to inner-shelf response to stepped sea-level rise: Insights from incised valleys and submerged shorelines}

Pretorius, L., Green, A. N., Cooper, A., Hahn, A., \& Zabel, M. (2019). Outer- to inner-shelf response to stepped sea-level rise: Insights from incised valleys and submerged shorelines. Marine Geology, 416, 1-14. [105979]. https://doi.org/10.1016/j.margeo.2019.105979

Link to publication record in Ulster University Research Portal

\section{Published in:}

Marine Geology

Publication Status:

Published (in print/issue): 31/10/2019

DOI:

10.1016/j.margeo.2019.105979

\section{Document Version}

Author Accepted version

\section{General rights}

Copyright for the publications made accessible via Ulster University's Research Portal is retained by the author(s) and / or other copyright owners and it is a condition of accessing these publications that users recognise and abide by the legal requirements associated with these rights.

\section{Take down policy}

The Research Portal is Ulster University's institutional repository that provides access to Ulster's research outputs. Every effort has been made to ensure that content in the Research Portal does not infringe any person's rights, or applicable UK laws. If you discover content in the Research Portal that you believe breaches copyright or violates any law, please contact pure-support@ulster.ac.uk. 


\section{Outer- to inner-shelf response to stepped sea-level rise: Insights from incised valleys and}

\section{2 submerged shorelines}

3

4 L. Pretorius1, A.N. Green1, J.AG. Cooper1,2, Hahn, A3., Zabel, M3

5

61. Geological Sciences, School of Agricultural, Earth and Environmental Sciences, University

7 of KwaZulu-Natal, Westville, South Africa

82. Environmental Sciences Research Institute, University of Ulster, Cromore Road, Coleraine,

9 Northern Ireland, UK

10 3. MARUM - Center for Marine Environmental Sciences, University of Bremen, Germany

11

\section{Abstract}

13 Shorelines respond to rising sea-level through processes such as erosion, landward migration

14 and in-situ drowning (i.e. overstepping). Submerged and preserved shorelines on the

15 continental shelf play a key role in examining coastal response to rising sea levels as they

16 provide important information on how modern shorelines may evolve in time and space within

17 the context of changing climate and post-glacial sea-level rise. This study identifies and

18 assesses the response of a continental shelf to stepped rises in sea level with particular focus

19 on the stepwise evolution of incised valleys and shorelines from the shelf-edge to the inner

20 shelf. Multibeam bathymetry data from the mid-outer allow for the analysis of seafloor

21 morphology, including the Protea Banks Reef (a palaeo-shoreline complex), and the adjacent

22 incised, sediment starved continental shelf. Six seismic units and intervening surfaces are 
23 identified using interpretations from sub-bottom profiles, these include the incised acoustic

2

24 basement, variable incised valley fill successions, aeolianite ridges and posttransgressive

25 shoreface and associated sediments that withstood wave ravinement processes. The incised

26 valleys of the outer-shelf are manifested as distinctive seafloor depressions, filled at their bases

27 by fluvial deposits overlain, in the unfilled valley, by deposits derived from cascading

28 subaqueous dunes which comprise the upper-most post-transgressive sediments. A core

29 intersecting the dune material yields a maximum age of deposition of 12751191 - 1263 cal. yr

30 B.P,BP (68\% range), synchronous with a period of higher than present sealevels in the region

31 suggesting reworking and redistribution of coastal sediment as shelf sediment post-

32 transgression. During the stepped rises in sea level, the shoreface has disconnected from the

33 contemporary shoreline and is preserved by means of topographic barriers formed by

34 antecedent topography as relict shoreface deposits. We provide a new perspective of shoreline

35 response to stepped rises in sea level by integrating the seismic architecture of incised valley

36 fills and shorelines across the continental shelf thus allowing for the assessment of variation in

37 rates of relative sea-level rise since the last glacial maximum.

\section{Keywords}

39 ShorelinePalaeo-shorelines, Preservation potential, Shoreface, Incised-valley, Overstepping

40

\section{Highlights}


42 ? Unfilled incised-valleys during transgression because of a lack of sediment and/or an increase

43 in accommodation space associated with a rapid increase in sea level.

44 ? Confinement points created by aeolianite barriers on the outer-shelf prevent sediment

45 stripping by the Agulhas current, suggesting antecedent controls on the preservation of

46 shoreline deposits.

47 ? Preservation of shoreline barriers by overstepping is related to the ensuing meltwater

48 pulses $1 \mathrm{~A}$ and $1 \mathrm{~B}$.

3

49 ? During the stepped rises in sea level, the shoreface has disconnected from the

50 contemporary shoreline.

51 ? A reduction of sediment supply for back-barrier/beach and shoreface exchange during

52 subsequent shoreline construction could lead to increased rates of shoreline retreat and

53 potentially overstepping of low-lying coastal areas.

54

55

\section{Introduction}

57 Barriers and associated shorelines respond to sea-level rise by three archetypal processes.

58 These include an erosional response, landward migration in step with sea-level rise, or

59 overstepping of the shoreline and in-situ drowning of the shoreline deposits (Cattaneo and

60 Steel, 2003; Cooper et al., 2018a). In the context of globally rising sea-levels and associated

61 risks from erosion and coastal inundation (e.g. Saito 2001; Thanh et al. 2004;

Gibbons and

62 Nicholls 2006; Blum and Roberts 2009), significant planning to mitigate the future economic, 
63 environmental and social impacts of such "coastal squeeze" (Mellet et al., 2018) needs to be

64 made. The understanding of shoreline behaviour under past and future conditions of sea-level

65 change can be assisted by investigations of Holocene shoreline deposits on the continental

66 shelf.

67 Submerged and preserved shorelines of the seafloor play a key role in examining coastal

68 response to rising sea levels. Their preservation in relation to antecedent gradient (Green et al.,

69 2018), rates of sea-level rise (Locker et al., 1996; Green et al., 2014) and sediment supply

70 (Mellet et al., 2012) relay important information on how modern shorelines may evolve in time

71 and space in the context of changing climate and post glacial sea-level rise.

4

72 The postglacial evolution of submerged shorelines has received much recent attention (Gardner

73 et al., 2007; Storms et al., 2008; Maselli et al., 2011; Green et al., 2012, 2013a; Mellett et al.,

74 2012; Salzmann et al., 2013; Pretorius et al., 2016) and has been shown to be intimately linked

75 to stepped rises in sea level throughout the Late Pleistocene to Holocene.

Shoreline-associated

76 and co-occurring shoreface and incised valley deposits also provide valuable information on

77 the evolution of coastal systems during and after transgression. This study thus aims to identify

78 and assess the response ofln particular, shelf-hosted incised valley systems may hold important

79 clues to the relative balance between postglacial rises in sea level and available sediment. In

80 this regard, Cooper et al. (2012) proposed a tripartite classification scheme for incised valleys. 
81 "Keep-up" incised valleys maintain infilling in pace with rising sea level, as such their fills are

82 mostly uniform sands. As Cooper et al. (2012) state “Such ‘keep-up' estuaries are

83 comparatively rare and occur only where conditions of high sediment supply kept pace with

84 the very high rates of sea-level rise in the early to mid-Holocene". "Catch-up" incised valleys

85 form when sea-level rises initially outpace sediment inputs, with a deep

system forming, then

86 later, during stable or slower rising sea levels, the system fills with marine or fluvial materials.

87 The last example is the "give-up" system. Here, sea level increases as a rate significantly

88 greater than can be balanced by sediment supply and the system is effectively drowned. There

89 is insufficient sediment to produce an incised valley fill, or the classic

"sediment sandwich" of

90 Ashley and Sheridan (1994). Give-up systems thus point to situations where sea-level rise has

91 been dramatic, or there has been a significant reduction in sediment form either marine or

92 fluvial sources.

93 Using a series of newly discovered submerged shorelines and multiple give-up, or underfilled

94 incised valleys exposed on the seafloor, we examine the shelf morphology and stratigraphy of

95 a portion of current-swept shelf from the South African margin. By virtue of the high levels

96 of preservation of these geomorphic forms on the shelf, we aim to identify and assess the

5

97 response of such a shelf to stepped rises in sea level. In particular, we focus on the stepwise 
98 evolution of incised valleys and shorelines from the shelf-edge to the inner shelf; and consider

99 the general evolution of the associated shoreface in this regard.

100

101 2. Regional Setting

102 The southern KwaZulu-Natal continental shelf is narrow $(\sim 8 \mathrm{~km})$ and steep $\left.\left(\sim 0.6^{\circ}\right) 6^{\circ}\right)$ when

103 compared to global averages $\left(75 \mathrm{~km}\right.$ and $0.1^{\circ}, 1^{\circ}$, respectively) (Shepard, 1963). The shelf

104 break occurs at $\sim 100$ m water depth and marks the transition from the continental shelf to the

105 upper-continental slope (Fig. 1) (Green et al., 2013a).

106 The KwaZulu-Natal coastline is wave-dominated throughout the year, with a significant wave

107 height of $1.8 \mathrm{~m}$ (Moes and Rossouw, 2008). The coastline is upper microtidal with a spring

108 tidal range of $1.8 \mathrm{~m}$ (Moes and Rossouw, 2008). The continental shelf is swept by the poleward

109 flowing Agulhas current which accounts for the overall sediment starved nature of the shelf

110 (Fig. 1) (Martin and Flemming, 1988; Green and McKay, 2016).

111 The acoustic basement of most of KwaZulu-Natal comprises seaward prograding Cretaceous-

112 aged siltstones which can be traced north to the central and northern KwaZulu-Natal

113 continental shelf (Green and Garlick, 2011; Cawthra et al., 2012; Green et al., 2013a; Salzmann

114 et al., 2013). The shelf has been incised by a network of valleys during past lowstand events

115 (Green et al., 2013b) the most recent of which was the Last Glacial Maximum (LGM) of

$116 \sim 18000$ yr BP when sea-level was 120 m below present (Fig. 11) (Cooper et al., 2018b). The

117 contemporary coast contains the estuaries of the Mzumbe and

MzimkuluUmzimkulu rivers, 
118 whose seaward extensions can be traced offshore as incised valleys.

6

119 Overlying the Cretaceous siltstones is Protea Banks, comprising a set of positive seabed

120 features with ridges whose crests occur at depths of $>30 \mathrm{~m}$ in the southern portion of the study

121 area (Fig. 1). theThe surface morphology includes linear ridges and parabolic plan forms.

122 These features correspond to areas north of the study area, where several shore-parallel ridge

123 features composed of aeolianite and beach rock material that represent former shoreline

124 occupations (Green et al., 2014) occur and are considered to be late Pleistocene-Holocene in

125 age (Martin and Flemming, 1987). The overall topography of the seafloor is rugged and uneven

126 with a gentle seaward dipping gradient of $0.2^{\circ}$. The shelf break is linear and occurs at $100 \mathrm{~m}$

127 water depth.

128 A discontinuous sediment wedge drapes the shelf and its surface features, with Cretaceous

129 siltstones sub-cropping a winnowed gravel pavement on the outer-shelf edge (Flemming,

130 1980).

131

\section{3. Materials and Methods}

133 Bathymetric data were collected using a WASSP WMB 3250 multibeam sonar system.

134 Accurate positioning ( $<30 \mathrm{~cm}$ RMS horizontal) was achieved using a Hemisphere VS330 Real

135 Time Kinematic (RTK) and heading system, with the RTK base correction. Motion correction 136 was applied by a $x$ Sens MTi-G motion reference unit mounted at the WMB 3250 transducer. 
137 Sound velocity profiles were collected with a Valeport MiniSVP. The bathymetric data were

138 corrected with RTK tides with an averaging of 300 seconds. The multibeam data were then

139 post-processed employing a three-step procedure including: 1) Processing of navigation data

140 for movement and physical properties of the water column such as roll, pitch, heave, tide, draft

141 and sound velocity; 2) Operator based processing, manual removal of artefact data points; 3)

142 Application of CUBE ${ }^{\text {TM }}$ filter and TIN (Triangular Irregular Networks) using HypackTM

7

143 software. TheseThe data were manually inspected, and point removal was carried out. The final

144 bathymetric colour image map was produced using Golden Software Surfer 12 withthen

145 exported as a data resolution of $102 \times 102 \mathrm{~m}$ grid.

146 High-resolution seismic profiles were collected using a 200J sub-bottom profilerApplied

147 Acoustics boomer, coupled to an 18-element hydrophone array. The data were collected and

148 processed using HypackTM software that included the application of timevaried gains, band-

149 pass filtering $(300-1200 \mathrm{~Hz})$, swell filtering, and manual seabed tracking.

Streamer layback

150 and antenna offset corrections were applied to the digitized data set, and constant sound

151 velocities in water $(1500 \mathrm{~m} / \mathrm{s})$ and sediment $(1600 \mathrm{~m} / \mathrm{s})$ were used to extrapolate all time-depth

152 conversions. The vertical resolution of these data is $\sim 5070 \mathrm{~cm}$. (Brown, 2011). Ultra high-

153 resolution seismic profiles were collected using a PARASOUND parametric echosounder 
154 aboard the RV Meteor, during cruise M123. The low frequency output (3.5 $\mathrm{kHz}$ ) was selected

155 due to signal attenuation of the higher-frequency spectra. The data were despiked and match-

156 filtered, and the envelope data exported in SEGY format for visualization in HypackTM. These

157 data resolve to $\sim 10 \mathrm{~cm}$ in the vertical domain. (Brown, 2011).

158 A four metre-long core (GeoB20622-2) was acquired, from location $30^{\circ} 45.301^{\prime}$ s; $30^{\circ} 35.520^{\prime} \mathrm{E}$ at

159 a depth of $\sim 80$ m below mean sea level, aboard the Meteor RV M123 cruise. An initial report

160 on the main sediment features can be found in order to examinethe cruise report published by

161 Zabel (2016). The sediment core allowed for the examination of the subsurface stratigraphy

162 of the study area and to conduct ground-truthing of the seismic results. The core was collected

163 using a 100-mm-diameter, five metre-long marine vibro-corer from a water depth of $90 \mathrm{~m}$ (Fig.

1641 ). The cores were split into archive and working halves, scanned immediately after opening

165 using a smartcube (C camera image scanner capturing high resolution digital photographs, and

166 logged according to standard Indian Ocean Drilling Project (IODP)GeoB sedimentological

167 procedures. The core was sub-sampled for AMS $\mathrm{C}_{14}$ dating, microfossils and grain size

8

168 analyses. The AMS $C_{14}$ dates were calibrated using OXCAL software (Ramsey, 2001) and the

169 marine13.14c calibration model (Reimer et al. 2013). The marine $\Delta R$ is assumed to be $121 \pm 16$

$170{ }^{14} \mathrm{C}$ yr (Maboya et al. 2017). Despite there being $4 \mathrm{~m}$ worth of core material, only one intact 
171 bivalve was discovered. Datable materials (such as life-position articulated bivalves)

172 accumulating in wave-dominated and current-swept shelves are notoriously difficult to find

173 due to the extent of reworking of the substrate. Furthermore, the high energies preclude the

174 accumulation of organic-muds, most of the sediments are considered palimpsest (Flemming,

175 1980).

176 Grain size analyses at 5cm intervals downcore were performed at the Center for Marine

177 Environmental Sciences (MARUM) in Bremen, Germany, using standard laser diffraction

178 analysis.a Coulter LS-13320 machine. The samples were pre-treated prior to analysis removing

179 organic and carbonate fractions. The grain size analysis measured grain size contents in 117

180 classes which ranged from 0.04 to $2000 \mu \mathrm{m}$ as a volume percent (vol\%).

GRADISTAT

181 software (Blott and Pye, 2001) after the Folk and Ward (1957) method were used to calculate

182 the first moment statistics.

183 4. Results

184 4.1. Seismic stratigraphy

185 Six units and intervening surfaces were identified using interpretations from $\sim 67$ line-km ultra-

186 high resolution PARASOUNDthe sub-bottom profiles and 104 line-km $200 \mathrm{~J}$, $600 \mathrm{~Hz}$ high

187 resolution sub-bottom profiles (Fig. 1).. A summary of the seismic facies and intervening

188 surfaces is indicated byprovided in Table 1 .

189 Unit 1

190 This unit is uncommon and was evident only in two shore perpendicular section extending off 
191 the southern headland of the Umzimkulu River (Figs. 2 and 3). Unit 1 is acoustically opaque.

9

192 The upper limit of Unit 1 is marked by a very high amplitude, undulating reflector (Surface 1)

193 (Fig. 2).

194 Unit 2

195 Unit 2 downlaps Unit 1 forming an unconformity, Surface 1 (Fig. 2). This unit is subdivided

196 into two sub-units based on varying dip angle:

197 Unit 2.1.

198 Unit 2.1 comprises seaward dipping (12.5 ), moderate to low amplitude, prograding reflectors.

199 This unit crops out at the sea floor from the inner-shelf to mid-shelf and is planed off and

200 incised by Surface 2 (Fig. 3). Unit 2.1 is unconformably overlain by Unit 2.2 at its most seaward

201 extent in the mid-shelf (Figs. 2 and 3).

202 Unit 2.2.

203 Similar toLike Unit 2.1.,, Unit 2.2 comprises moderate to low amplitude, seaward prograding

204 reflectors that dip at a steeper angle $\left(\sim 20^{\circ}\right)$ (Fig. 3). This unit crops out on the seafloor from

205 the mid-shelf to the shelf edge (Figs. 3 and 4). Unit 2.2 is similarly truncated and incised across

206 the entire shelf by Surface 2 .

207 Unit 3

208 Unit 3 comprises moderate to high amplitude, prograding seismic reflectors (Fig. 5a). This unit

209 is isolated in occurrencedoes not frequently occur and when it does, it occurs in association

210 with Unit 6.1. It directly onlaps the acoustic basement within topographic depressions

211 occurring from the mid-shelf to outer-shelf and is planed off by a moderate to high amplitude 
212 seismic reflector/surface, Surface 3.

213 Unit 4

10

214 Unit 4 can be subdivided into three sub-units. Unit 4.1 comprises moderate amplitude,

215 prograding reflectors that onlap Surface 2 (Figs. 2c, 3b, 4a and 4c). Unit 4.1

occurs at the base

216 of incisions in Surface 2 and is capped by Surface 4. Unit 4.2 comprises either steep, larger-

217 scale, moderate amplitude, prograding seismic reflectors; moderate amplitude, seismic

218 reflectors onlapping Surface 2 (Figs. 2c, 3b, 4a and 4c); or poorly-developed, moderate

219 amplitude, discontinuous and chaotic seismic reflectors (Fig. 2b). Unit 4.3 is not always present

220 in the study area (FigsFig. 4a). Where it does occur, Unit 4.3 is separated from Unit 4.2 by a

221 gently dipping, high amplitude erosional seismic reflector (Surface 5) and onlaps units 2 and

2224.2 (Figs. 2c, 3b, 4a and 4c). Unit 4.3 is composed of horizontal, subparallel to chaotic,

223 discontinuous seismic reflectors (Figs. 2c, 3b, 4a and 4c). In cases where the incisions of

224 Surface 2 are less wide and deep, Unit 4 appears massive with a poorly developed internal

225 structure (ege.g. Figs. 2b and 6b7b). Unit 4 is truncated by a high amplitude, flat lying erosional

226 reflector, Surface 6, which merges with Surfaces 2, 3 and 5 to form a composite erosional

227 surface 2/3/5/6 (Fig. 4c).

228 Unit 5

229 This rugged unit crops out on the sea floor and is acoustically opaque, with no internal seismic

230 configuration (Figs. 2a, 3a, 5b, 5c and 7a). It is most abundant in the southern portion of the 
231 study area and crops out in the mid-shelf to outer-shelf region at depths of 40 $\mathrm{m}$ and greater.

232 Unit 5 is strongly associated with Unit 6.2 as it is often onlapped by Unit 6.2 (Figs. 2c, 3a, 2c,

$2335 b, 5 c$ and $7 a)$. Where Unit 5 sub-crops, it is capped by a very high amplitude seismic reflector,

234 Surface 67, that in some localities crops out as part of the sea floor (Fig. 7a). 235 Unit 6

236 Unit 6 can be subdivided into three sub-facies based on their seismic character and distribution

237 on the shelf. Unit 6.1. consists of moderate to low amplitude, continuous, semi-parallel seismic

11

238 reflectors and onlaps the combined surface of 2/4 (Figs. 3b, 4c, 5a, 6a and 7b). From the ultra-

239 high resolution seismic data, the reflectors are arranged in a semi-parallel configuration (Figs.

$2403 \mathrm{~b}, 4 \mathrm{c}, 5 \mathrm{a}, 6 \mathrm{a}$ and $7 \mathrm{~b})$. This unit is most often situated in the in-shore portion of the shelf (Figs.

$2412,3 b, 4,5 a, 6$ and 7). Unit 6.2. rests within depressions of Surface 5 and comprises moderate

242 amplitude onlapping, occasionally chaotic, discontinuous seismic reflectors (Fig. 2a, 3a, 4a, 5b

243 and $5 \mathrm{c}$ ). This unit has a semi-opaque and occasionally shingled internal character and is capped

244 by Surface 78 (Fig. 7a). Figure 5b shows the weak development of seawardoblique prograding

245 foresets in subunitUnit 6.2. Unit 6.3. is present mainly in the mid-shelf region (Figs. 2c, 3a, 4a,

$2464 \mathrm{~b}, 5 \mathrm{a}, 5 \mathrm{~b}$ and $7 \mathrm{a}$ ). It is characterized by moderate amplitude, finely mottled reflector packages

247 with larger scale bedding planes. This unit has an average thickness of $\sim 4 \mathrm{~m}$ but can reach up

248 to $\sim 7 \mathrm{~m}$ thick within the topographical troughs formed by Unit 5 (Fig. 7a). 
249 Table 1. A summary of seismic stratigraphic units, separating stratal surfaces and, interpreted

250 depositional environments and stratigraphic ages.

Unit/

Sub-unit

Overlying

Surface

Seismic Description Interpretation of Depositional

Environment

U1 Acoustically opaque Granite-gneiss complexe of the Namaqua-

Natal Metamorphic Province (Cornell et

al., 2006)

S1 High amplitude, undulating Sequence Boundary (SB)

SU2.1 Seaward dipping $\left(\sim 12.5^{\circ}\right)$, low

amplitude, prograding

Siltstone

S2 Maximum Flooding Surface (MFS)

(Green and Garlick, 2011)

SU2.2 Seaward dipping $\left(\sim 20^{\circ}\right)$, low

amplitude, prograding

Siltstone (Green and Garlick, 2011)

S3 High amplitude, truncates and

incises Unit 2

Sequence Boundary (SB1) (Green and

Garlick, 2011)

3 Isolated, onlapping high

amplitude, prograding

Relict shallow near-shore facies (Green,

2011)

S4 Moderate to high amplitude Sequence Boundary?

SU4.1 Onlaps S2, moderate amplitude,

prograding

Fluvial lag

12

S5 Low to modereate amplitude Transgressive surface (Ts) (Nummendal and Swift, 1987)

SU4.2 Onalps S2, steep, moderate 
amplitude, prograding

Central basin-fill (Zaitlin et al., 1994;

Green et al., 2013b; Allen and

Posamentier, 1994)

S6 High amplitude, uneven Tidal ravinement surface (TRs)

SU4.3 Horizontal, sub-parallel to

chaotic discontinuous,

retrograding

Sandy estuarine barrier (Cooper, 2001;

Nordfjord et al., 2006; Green et al.,

2013b)

S6 Very high amplitude, rugged Wave ravinement surface (WRS)

5 Acoustically opaque, crops out

on sea-floor

Aeolianite barriers (Green and Garlick,

2011)

S6 Same as above -

SU6.1 Moderate to low amplitude,

continuous, semi-parallel

Contemporary shoreface (Martin and

Flemming, 1986)

SU6.2 Onlapping, moderate amplitude,

occasionally chaotic,

discontinuous, semi-opaque,

shingled, weakly seaward

oblique prograding

Palaeo-shoreface (Martin and Flemming,

1986)

S7 Weakly visible, low amplitude FS?

SU6.3 Moderate amplitude, finely

mottled, larger scale bedding

planes

Pebble-floored coarse sand with

bioclastics. Shelf dunes, highstand

sediment (Flemming, 1980; Green, 2009)

251

252 4.2. Seafloor morphology 
253 Multibeam bathymetry of the mid-outer shelf provides additional information on the seafloor

254 morphology including the Protea Banks Reef portion and incised continental shelf.

255 The outer shelf comprises a series of alternating linear, shore parallel, arcuate and ridge features

256 occurring at $60 \mathrm{~m}$ and $100 \mathrm{~m}$ depth. These ridge features have $\sim 5-10 \mathrm{~m}$ relief above the sea

257 floor (Figs. 8b and 8c), and in some areas exist as multiple parallel ridges over a distance

258 spanning 200-300 m (Fig. 8b). These ridges correspond to seismic Unit 5.

259 The shelf seaward of the ridges comprises undulating seafloor defined by NESW striking

260 linear features. These linear features have gentle relief and mimic the contour of the present13

261 day shoreline. They represent the foresets of seismic Unit 2.2 cropping out on the seafloor and

262 extending to the continental shelf break (Figs. 3, 4 and 8).

263 The shelf is marked by sinuous to linear seafloor depressions with negative relief of $\sim 20 \mathrm{~m}$ and

264 widths ranging between $400-800 \mathrm{~m}$ (Figs. 8d and 8e). The seafloor depressions trend

265 perpendicular to both the ridges and the modern-day shoreline. These depressions are

266 dominantly asymmetrical U-shaped with gently, across-channel, sloping floors. The walls and

267 floors of the depressions correspond with seismic Surface 2 and Unit 6.3, respectively (Figs.

$2684 a$ and 9). Seaward of the ridge features, the depressions terminate in funnellike depressions

269 at $\sim 65 \mathrm{~m}$ depth (Figs. 8d and 9).

270 The depth structure surface of Surface 2 indicates a clear continuation of incision of the 
271 MzimkuluUmzimkulu river and associated tributaries over the continental shelf towards the

272 shelf break (Fig. 9). Underlying part of Protea Banks is a basement high in the southern portion

273 of the study area. Basement depressions at stratigraphic depths of $65 \mathrm{~m}$ link up with less

274 pronounced, coast-perpendicular channels which terminate on the outershelf at low-lying sites

275 topped with arcuate spit features, and merge with underfilled valleys and seafloor depressions

276 (Fig. 8b and c; 9).

277

278 4.3. Lithostratigraphy and chronostratigraphy

279 The basal facies of Core GeoB20622-2the sediment core comprises an approximately $2.5 \mathrm{~m}$

280 thick succession consisting of poorly sorted, very coarse sand with shell fragments and pebble

281 clasts at the base (Fig. 10). The grain sizes fine upward from very coarse sand to coarse sand

282 with occasional gritty sub-rounded quartz (Fig. 10). The lower facies correlates with seismic

283 Unit 6.3 (Fig. 4a and Table 2).

14

284 The lower facies is truncated by a horizontally-orientated quartz pebble layer and overlain by

285 a 1.4 m thick unit of medium to coarse sand with alternating bands of muddy sand (Fig. 10a).

286 All the pebbles are homogenous in size with respect to their $a-b$ - and $c$ - axis (Figs. 10b-d).

287 The a- axes average $\sim 7.5 \mathrm{~cm}$ with the $\mathrm{b}$ - and $\mathrm{c}$ - axes $\sim 5.5 \mathrm{~cm}$ and $\sim 3 \mathrm{~cm}$ respectively. The b-

288 axis is defined as the maximum horizontal width of the clast (Krumbein, 1939). The angle and

289 orientation of the $b$-axis of pebbles can provide information on the depositional environment. 
290 All the pebbles rest with their b-axes perpendicular to the seafloor (Fig. 10a). 291 The upper unit is devoid of pebbles. The overall sediment composition of the Unit 6.3 is

292 majority quartz with lesser amounts of feldspar, lithic fragments and bioclastic fragments.

293 (comprising bivalve shell debris, bryozoa and coral). The upper Unit corresponds with seismic

294 Unit 6.3 (Fig. 4a and Table 2). An intact gastropod shell, from the facies boundary that these

295 pebbles mark, yields a ${ }_{14} \mathrm{C}$ age of $1275 \pm 301191$ - 1263 cal. yr BP. (68\% range).

296 Table 2 Summary of core sediment facies and faunal descriptions relative to seismic

297 stratigraphy

Core Facies Thickness Sediment description Fauna Seismic Unit

Lower facies $2.5 \mathrm{~m}$ Poorly sorted, very coarse

quartz-rich sand, shell fragments

and pebbles at base. Upward

fining.

Sublittoral

marine taxa (i.e.

echinoderm and

brachiopod)

Unit 6.3

Boundary Quartz pebbles Internal master bedding

plane (Allen, 1982)

Upper Facies 1.5 m Majority quartz with lesser

feldspar and lithic, and

bioclastic fragments. Devoid of

pebbles.

Rounded

calcareous

bioclasts

Unit 6.3 
15

\section{4.4. Biostratigraphy}

300 Core GeoB20622-2The core generally comprises fragmented and abraded marine sublittoral

301 fauna. The lower facies of the core (at $\sim 361-362 \mathrm{~cm}$ depth down core) hosts fragmented

302 marine taxa (i.e. echinoderms and gastropods), while the upper facies (at 138-139 cm depth

303 down core) hosts rounded bioclasts of calcareous nature (Frenzel, $P$, pers.

Comm.). These

304 faunae correspondThis lithofacies corresponds to unitUnit 6.3 (Table 2).

305

306 5. Discussion

307 5.1. Seismic Stratigraphy

308 Seismic Unit 1 forms the acoustic basement of the study area and is considered to correspond

309 to the crystalline basement that crops out along the adjacent shoreline. These crystalline rocks

310 are overlain by Seismic Unit 2, the seismic architecture of which has been recognised

311 throughout the region as belonging to seaward-dipping Cretaceous age siltstones (Green and

312 Garlick, 2011). The capping erosional surface, Surface 2 is considered to represent the most

313 recent subaerial unconformity (e.g. Green, 2009; Pretorius et al., 2016) that formed as sea-level

314 fell to the LGM at 125 m depth (Green and Uken, 2005; Cooper et al., 2018b).

315 Surface 2 reveals that the palaeo-MzimkuluUmzimkulu river incised the basement rocks during

316 regression associated with the Last Glacial maximum (Fig. 9). The drainage network bypassed

317 a basement high of Unit 2 in the southern region, indicating a geomorphological control on the 318 passage of incised valleys across the continental shelf. 
319 Seismic Unit 3 is a localised unit found in shallow depressions within Unit 2 at $-60 \mathrm{~m}$ and at -

$320150 \mathrm{~m}$, respectively. Seismic Unit 3 is comparable to remnant prograding coastal deposits

321 documented on the mid-shelf and at the shelf edge of the eastern Tyrrhenian Sea margin

16

322 (Trincardi and Field, 1991). Green (2011) considered similar deposits to the north of the study

323 area to represent shallow nearshore facies of indeterminable age. Their preservation appears to

324 be controlled by their location on interfluves and in shallow topographic depressions which

325 provided shelter from the erosional processes associated with the overlying wave ravinement

326 surface. Trincardi and Field (1991) proposed that the sheer volume of the Tyrrhenian Sea

327 deposits was the main factor contributing to their successful preservation.

Their patchy

328 distribution in the study area suggests that they may have been only locally developed.

329 Unit 4 represents a succession of incised valley fill deposits. The basal portions of chaotic,

330 discontinuous reflectors (Unit 4.1) represent coarse fluvial channel lags and, when prograding

331 in a shore-parallel orientation, point bar deposits (cf. Weber et al., 2004;

Green and Garlick,

332 2011; Green et al., 2013b). The capping reflector, Surface 45, delineates the initial flooding of

333 the fluvial system during the ensuing postglacial transgression and is interpreted as the

334 transgressive surface (TS) (see Nummedal and Swift, 1987).

335 The mid portions of the valley fills (Unit 4.2) overlie this surface. The subparallel, and, in 
336 some cases, horizontal onlapping configurations have been recognized by many authors as

337 indicative of the central basin fill of a developing wave-dominated (e.g. Zaitlin et al., 1994;

338 Green et al., 2013b) or mixed wave-tide dominated (Allen and Posamentier, 1994) estuary.

339 Unit 4.2 is capped by an inclined, channel shaped, high amplitude reflector interpreted as the

340 tidal ravinement surface. (S6). The tidal ravinement surface is best preserved on the inner-shelf

341 portion whereas a horizontal, flatter high amplitude reflector tops Unit 4.2 on the outer-shelf

342 segment, if present at all.

343 The upper fill (Unit 4.3) is variable along dip. Horizontal sub-parallel chaotic discontinuous

344 reflectors indicate a retrogradational character and this unit likely represents small scale sandy

345 estuarine barriers such as those seen offshore Durban (Nordfjord et al., 2006; Green et al., 17

$3462013 b)$ and on the modern coast (Cooper, 2001). This sub-unit represents the transgressive

347 systems tract of the incised valley fill succession.

348 Unit 5 is a rugged, acoustically opaque unit that crops out on the sea-floor.

This unit is

349 interpreted as cemented aeolianite ridges and barriers of relict shorelines.

These occur at

350 various localities on the southeast African shelf (Martin and Flemming, 1987; Green et al.,

351 2014; Pretorius et al., 2016). These deposits) and record the depths of past stillstands during

352 which significant shoreline deposits accumulated. They record shorelines from depths of -60

$353 \mathrm{~m}$ and greater (Fig. 11) (Pretorius et al., 2016; Green et al., 2018). Unit 5 and sub-unitUnit 4.3 
354 are capped by the postglacial wave ravinement surface (S7) (see Pretorius et al., 2016).

355 Seismic Unit 6 represents the post-transgressive shoreface and associated sediments that

356 survived wave ravinement processes on the continental shelf. The contemporary shoreface

357 wedge (Sub-unitUnit 6.1) appears as a thin package in the inner-shelf (Martin and Flemming,

358 1986), whereas the offshore sub-unitUnit 6.2 represents palaeo-shoreface deposits that have

359 been decoupled from the contemporary wedge during shoreface translation (Pretorius et al.,

360 2016). Unit 5 deposits act as obstacles that feed back into the shore translation process and

361 inhibit the movement of the complete shoreface as it migrates landward, hence leaving

362 remnants (Unit 6.2) behind. Unit 6.2 deposits are preserved when they are situated in

363 depressions in Unit 5 and are sheltered to a degree from the mid- to outershelf current

364 sweeping (Flemming 1980) by the Agulhas Current.

365 Unit 6.3 occurs as thin deposits from the mid-shelf to outer-shelf and as a fill in the underfilled

366 incised valleys of the outer shelf. These fills comprise late Holocene age pebble-floored coarse

367 sand and bioclastic successions. The bioclastic components of the core are wholly composed

368 of marine sub-littoral shell fragments and rounded calcareous clasts.

Flemming (1980)

369 observed large to very large dunes forming in coarse sand and fine gravels across this shelf

18

370 region along the east coast of South Africa. Green (2009) observed similar bedforms off the 
371 northern KwaZulu-Natal coast and attributed them to current-reworking of shelf sands and

372 gravels comprising modern highstand sediments.

373 The date obtained from the upper portion of the outermost underfilled incised valley indicates

374 a maximum age of deposition of 12751191 - 1263 cal. yr B.P,BP (68\% range), which wasplaces

375 sea level within a periodmetre or two of higher thanthat of the present sealevels in the

376 regionday (Fig. 11) (Cooper et al., 2018b). The unit therefore accumulated on the shelf under

377 conditions similar to present. The horizontally-orientated quartz pebble layers indicate

378 stratification under current influence associated with the bases of migrating contemporary shelf

379 subaqueous dune fields (Martin and Flemming, 19922000). These are overlain by the main

380 dune body of sub-littoral sourced sands and shell debris which have cascaded into the incised

381 valleys and filled them.

382 The continental shelf, in its entirety, comprises a basement high coinciding with the $\sim 60 \mathrm{~m}$

383 isobath and resulted in less accommodation space, allowing for dunes to accrete and

384 concentrate on this portion of the continental shelf. Basement depressions along the $-60 \mathrm{~m}$

385 isobath show a widening of channel systems likely associated with slowstand events. These

386 depressions may represent low-lying back-barrier estuarine systems that were overstepped

387 during transgression.

\section{5.5.4. Facies architecture and distribution of incised valley fills across the shelf} 389 The extent and distribution of the incised valley facies varies systematically across the shelf. 
390 In the proximal inner-shelf segment, the fluvial Sub-unitUnit 4.1 makes upcomprises a large

391 portion of the incised valley-fill (Fig. 12a). Central basin deposits (subunitUnit 4.2) are

392 preserved and capped by tidal ravinement surfaces and then overlain by sandy barrier and 393 estuarine tidal inlet facies.

19

394 In the mid-shelf region, the incised valley fill succession is comparable to that of the inner-

395 shelf, although, with increasingly less volumes of fluvial material and an increase in volume

396 of the central basin fill (Fig. 12b). The barrier facies is separated from the central basin deposits

397 by a tidal ravinement surface and is capped by the wave ravinement surface.

398 The valleys of the outer-shelf retain a distinctive seafloor depression (Figs.

$8 d, 8 e, 10$ and 12c)

399 and are filled at their bases by fluvial materials above which, in the unfilled valley, they are

400 overlain by materials derived from cascading dunes (Fig. 12c). Payenberg et al. (2006), show

401 a direct equivalent from Hervey Bay, Australia, where incised valleys on the shelf are filled

402 with undifferentiated sandy material deposited into an exposed valley by migrating sub-

403 aqueous dune fields on the contemporary shelf.

404 The absence of the central basin and barrier facies of the transgressive systems tract in the outer

405 shelf valleys is striking (Fig. 12c). This relative underfilling of the valley during transgression

406 suggests decoupling from the sea level/sediment supply balance associated with transgressive

407 filling of estuaries (see Cooper et al., 2012). Such a scenario can occur either when sea-level 
408 rise is rapid (causing an increase in accommodation space) or when either fluvial or marine

409 sediment supply is significantly reduced. The presence of fluvial deposits in the valley fill

410 suggests that there was sufficient fluvial supply to the system prior to transgression. The valley

411 was unfilled during transgression because of a lack of sediment and/or an increase in

412 accommodation space associated with a rapid increase in sea level.

\section{5.3. Outer-shelf Morphology (shoreline at 100 m below MSL)Mean Sea Level)} 414 The series of aeolianite barriers of Unit 5 (Fig. 2a, 3a, 5b, 5c and 7a), are separated by small

415 topographic lows (Fig. 8b) and mark a -100 m palaeo-shoreline. The topographic lows have

416 similar scales and orientations to the modern inlets of barrier-lagoon systems of SE Africa (cf.

417 Cooper, 2001) and are consequently interpreted as remnants of barrier-inlet features of the 20

418 palaeo-shoreline. The -100 m palaeo-shoreline is intersected and underlain by valleys exposed

419 to the seafloor (Unit 4) (Fig. 9). Those valleys terminate in funnel shaped depressions at -100

$420 \mathrm{~m}$. The terminating morphology is identical to the morphology of riverdominated, microtidal 421 estuaries of southern Africa (cf. Cooper, 1993,1994, 2001) (Fig. 8). Though large dune fields,

422 intersected by small estuaries, are not evident on the adjacent contemporary coast, they are

423 common on sediment-rich coasts to both north (Jackson et al., 2014) and south (Cooper et al.,

4242013 ) of the study area. This suggests that past hydrodynamic conditions were like those of 425 today, however, a larger potential for barrier growth existed when sea levels were near $-100 \mathrm{~m}$. 
426 Here, the open shelf, then palaeo-coastal plain, promoted greater windfetches, in addition to

427 greater degree of accommodation whereby larger dunes could be built. In comparison, as sea

428 level has risen to the modern-day shoreline, the coast has since transformed into a series of

429 granitic headland-bound embayments and pocket beaches that, due to their steep and irregular

430 natures, lack sufficient accommodation to allow for large dune building to occur.

431 The series of arcuate and cuspate ridges, together with the seaward prograded smaller ridges

432 are surface continuations of Seismic Unit 5. Green et al. (2013a; 2014) were the first to describe

433 such features from the seafloor and considered these to be features of a back barrier lagoonal

434 shoreline produced by segmentation processes of a coastal waterbody (cf. Ashton et al., 2009).

435 These ridges co-occur with seafloor depressions and the seaward termination point of the main

436 Unit 5 barriers, estuaries and inlets. We thus consider them to have formed simultaneously with

437 the seaward growth, through normal regression, of the $-100 \mathrm{~m}$ palaeoshoreline.

438 The $-100 \mathrm{~m}$ shoreline corresponds in elevation to sea levels associated with the Bølling Allerød

439 period when sea level was at -100 m (Peltier and Fairbanks, 2006; Green et al., 2014). Recent

440 work suggests that the LGM involved two periods of sea-level stability separated by rapid sea-

441 level change (Yokoyama et al., 2018). As discussed by Salzmann et al. (2013), this general

442 period of sea-level stability was long enough to promote the development of planform 
443 equilibrium shorelines with localised areas of normal regression, forming arcuate back barrier

444 spits and large dune fields in equilibrium with prevailing energy conditions and sediment

445 supply (cf. Ashton et al., 2009).

446 The association of underfilled, incised valleys with this shoreline is notable. As discussed

447 above, these valleys on the outer shelf provide evidence for rapidly rising sea levels that left

448 the outer segments completely drowned in situ. Likewise, we envision the preservation of the

449 associated shorelines to be a result of sea-level rise that led to the rapid upprofile progression

450 of wave ravinement across the continental shelf, leaving less time for the breakdown of

451 shorelines in response to wave action and preserving shoreline deposits by overstepping (sensu

452 Swift, 1968). We link this to Melt Water Pulse (MWP) 1-A, which followed the LGM stillstand

453 and was associated with a $\sim 16 \mathrm{~m}(26-53 \mathrm{~mm} / \mathrm{yr})$ rise in sea level between 14.6 and $13.8 \mathrm{ka} \mathrm{BP.}$

454 This has been linked to other -100 m shorelines both locally (Salzmann et al., 2013; Green et

455 al., 2014) and globally (Peltier and Fairbanks, 2006; Liu and Milliman, 2004;

Fairbanks, 1989).

\section{5.4. Mid- to Outer-shelf ( $100 \mathrm{~m}$ to $60 \mathrm{~m}$ below MSL)}

457 The outer to mid shelf areas ( -60 to $-100 \mathrm{~m}$ ) are marked by the cropping-out foresets of Unit

458 2, with no sediment cover or shoreline features (Figs. 2, 3, 5 and 7). Following MWP-1A at

45913.6 ka cal. B.P. (Peltier and Fairbanks, 2006), the rate of sea-level rise decreased significantly

460 allowing wave ravinement processes to become more effective in eroding and reworking any 
461 existing deposits on the continental shelf (Fig. 12). Coupled with the contemporary erosion by

462 the Agulhas current, and the lack of shelter by aeolianite pinnacles or depressions in the LGM

463 subaerial unconformity, this has led to the complete sediment denudation of these areas by

464 erosion. Other examples of similarly sediment scarce, current swept shelves around the world

465 include the south-eastern shelf of the United States (Harris et al., 2013) and the North Adriatic

466 epicontinental shelf (Trincardi et al., 1994).

22

467

468 5.5. Mid-shelf (shoreline at $60 \mathrm{~m}$ below MSL)

469 The mid-shelf is marked by a second generation of preserved shoreline complexes at $-60 \mathrm{~m}$

470 (Figs. 2, 3, 5 and 7), overlying the LGM-aged incised valleys. Like the $-100 \mathrm{~m}$ shoreline,

471 remnant submerged shoreline complexes at this depth are prominent along the entire SE

472 African coast (Salzmann et al., 2013; Green et al., 2014; Pretorius et al., 2016;

De Lecea et al., 473 2017).

474 The set of shoals with U-shaped planforms in the shallowest upper portion of the aeolianite

475 field are interpreted as preserved parabolic dune fields (Fig. 8a). Parabolic dunes occur where

476 there are high rates of sediment supply, enough accommodation space to allow for accretion

477 (Oestmo et al., 2014) and strong, unidirectional winds driving sediment transport (Landsberg,

478 1956). These features indicate southwesterly unidirectional dune migration, as is the case for

479 the majority of parabolic dunes to the north of the study area (Jackson et al., 2014). The gentle 
480 relief of the palaeo-coastal plain (as evidenced in the subaerial unconformity) and the lack of

481 confining headlands accounts for the size of this dune field compared to the absence of any

482 dune fields in the contemporary coastal setting. The degree to which these aeolianites are 483 preserved points to rapid supra- and intertidal lithification of the dunes, commonly seen in

484 subtropical settings (Cooper and Green, 2016). Cooper et al. (2018b) consider prolonged sea-

485 level stability as a major contributor to the aeolian sediments having longer residence times in

486 the vadose zone, thus favouring the rapid lithification of dune bases. During the Younger Dryas

487 Period ( 12.8 cal Ka to $11.3 \mathrm{cal} \mathrm{Ka})$, the associated slowstand allowed enough time for the 488 construction and lithification of a prominent shelf-wide shoreline complex (Fig. 11) (Pretorius 489 et al., 2016).

23

490 At $11.3 \mathrm{cal} \mathrm{Ka}$, the rate of sea-level rise (13-15 mm/yr) (Liu and Milliman, 2004; Peltier and

491 Fairbanks, 2006; Cooper et al. 2018) is considered to have accelerated substantially (Green et

492 al., 2014) in response to Melt-Water Pulse 1B (MWP-1B) (Fig. 11). This rapid rise in sea level

493 lead to the swift overstepping and submergence of the $-60 \mathrm{~m}$ shoreline now left relict on the 494 shelf. The aeolianite barriers (Unit 5) and shoreline deposits were partially eroded and

495 deposited (Unit 6.2) within the hollows between confinement points created by the aeolianite

496 barriers (Unit 5) (Fig. 7).

497 5.5.6. Post-transgressive sediment on the shelf 
498 The morphological response of the shoreface to rapid sea-level rise takes longer than that of

499 adjacent barriers (Swift, et al., 1985; Cooper et al., 2018a), hence the shoreface retreat lags

500 behind the actual barrier migration (e.g. German Frisian barrier islands, Flemming and Davis,

501 1994; Fire Island, NY, Sanders and Kumar, 1975). During rapid sea-level rise, barriers separate

502 from the shoreface leaving it submerged, while the surf- and barrier-zones migrate rapidly

503 (Cooper et al., 2018a). The barrier then forms a subsequent shoreface by means of eroding the

504 underlying strata at its new stabilization point (Cooper et al., 2018a). The original shoreface

505 may remain drowned and stranded on the continental shelf or may continue to slowly migrate

506 landwards to 'catch-up' with the surfzone and beach system when the subsequent shoreline

507 stabilises (ege.g. Beets and van der Spek, 2000; Hijma and Cohen, 2010).

508 Cooper et al. (2018a) point out that reasons for this observed spatially variable relationship

509 between shoreface and barrier behaviour have not been investigated but may likely include

510 variability in geological controls and dynamic factors. We consider the midouter shelf pockets

511 of unconsolidated sediment on the seafloor, resting above the wave ravinement and always in

512 association with shoreline pinnacles to ebbe a good example of this. The -60 $m$ and $-100 m$

513 barrier shorelines acted as antecedent controls on the up-profile migration of shoreface

24

514 sediment, thereby restricting and reducing the volume of material available for the 
515 barrier/beach to exchange with landward migration of reworked shoreface sediment during

516 overstepping. This leadled to less sediment available for shoreface construction as the shoreline

517 migrated landward, thus leaving stranded segments of shoreface deposits on the outer shelf.

518 Following the assumptions of Davis and Clifton (1987), Pretorius et al. (2016) showed that on

519 the Durban shelf, rates of shoreface translation were manifestmanifested as changing gradients

520 in the ravinement profile. A steeper ravinement was linked with MWP-1B, whereas the flatter

521 inner-shelf ravinement was generated by slower rates of sea-level rise consequent with a

522 considerable slowstand period (Cooper et al., 2018b). A similar scenario is invoked here. The

523 inner-shelf shows limited preservation of shorelines with a lower gradient ravinement surface

524 attributed to consequent slower rates of sea-level rise where the shoreface has managed to catch

525 up the rising sea level.

526 Seaward of the $-100 \mathrm{~m}$ shoreline outer-shelf, there are few morphological barriers to cross-

527 shelf sediment transport deeper. Considering that sediments are usually deposited down profile

528 during transgressive erosion (Pretorius et al., 2017), the transgression from the $-100 m$

529 elevation likely shed eroded sediments off-shelf due to the steep and narrow nature of the

530 region. The finer sediment would also later be entrained southward by the Agulhas current as

531 bedload leaving winnowed shelf deposits where present.

\section{6. Conclusion}

533 The development of large aeolian dunes on the low-gradient palaeo-coastal plain of the 
534 continental shelf of Protea Banks indicates an open coastal plain palaeosetting with an absence

535 of geological controlled coastal compartments in contrast to the contemporary coast line. The

536 large, unimpeded accommodation space allowed for large dune fields and open water bodies

537 to develop.

25

538 The two sets of shorelines formed after the LGM and arewere related to stability of the

539 shoreline during the Bølling Allerød and Younger Dryas periods. We hypothesize that their

540 preservation, by overstepping, iswas related to the ensuing meltwater pulses $1 \mathrm{~A}$ and $1 \mathrm{~B}$.

541 The Holocene fill architecture of the co-occurring incised valley-fills show variation from the

542 inner-shelf to the outer-shelf. The outer-shelf incised valleys are conspicuously under-filled,

543 the fills comprise fluvial deposits truncated by wave ravinement and capped by contemporary

544 shelf/dune sand deposits. The infill pattern is related to rapid overstepping of the shoreline due

545 to MWP-1A. The inner shelf valleys conversely reflect a period of relatively slow sea-level

546 rise which kept pace with sediment supply.

547 We show that during the stepped rises in sea level, the shoreface has disconnected from the

548 contemporary shoreline. The role of antecedent topography is considered, together with the

549 rapid rises in sea level, to produce the dislocation and preservation of relict shoreface sediment

550 on the continental shelf. Given future predictions in sea-level rise, and the local onshore

551 bedrock controls, a reduction of sediment supply for back-barrier/beach and shoreface 
552 exchange during subsequent shoreline construction could lead to increased rates of shoreline

553 retreat and potentially overstepping of low-lying coastal areas.

\section{Acknowledgements}

555 We acknowledge the captain and crew of the RV Meteor, cruise M123. We further

556 acknowledge our colleagues on the cruise, Matthias Zabel, Errol Wiles, Talicia Pillay, Hayley

557 Cawthra, Nadia Du Plessis, Sergio Andò, and Peter Frenzel, and Annette Hahn. Environmental

558 Mapping and Surveying and the African Coelacanth Ecosystem Programme (ACEP) are

559 thanked for assistance in the collection of bathymetry. This project was funded under the 560 auspices of Regional Archives for Integrated iNvestigations (RAiN) and ACEP.

LP

26

561 acknowledge scholarships from the South African Institute for Aquatic Biodiversity and the

562 National Research Foundation (Grant No.103115).

\section{References}

564 Allen, J.R.L., 1982. Sedimentary structures, vol. II. Developments in Sedimentology, 30.

565 Allen, G.P. and Posamentier, H.W., 1994. Sequence stratigraphy and facies model of an incised

566 valley fill; the Gironde Estuary, France. Journal of Sedimentary Research, 63, pp.378-391.

567 Ashton, A.D., Murray, A.B., Littlewood, R., Lewis, D.A. and Hong, P., 2009. Fetch-limited

568 self-organization of elongate water bodies. Geology, 37, pp.187-190.

569 Beets, D.J. and van der Spek, A.J., 2000. The Holocene evolution of the barrier and the back-

570 barrier basins of Belgium and the Netherlands as a function of late Weichselian morphology, 
571 relative sea-level rise and sediment supply. Netherlands Journal of Geosciences, 79, pp.3-16.

572 Blott, S.J. and Pye, K., 2001. GRADISTAT: a grain size distribution and statistics package for

573 the analysis of unconsolidated sediments. Earth surface processes and Landforms, 26, pp.1237-

5741248.

575 Blum, M.D. and Roberts, H.H., 2009. Drowning of the Mississippi Delta due to insufficient

576 sediment supply and global sea-level rise. Nature Geoscience, p.p.488-491.

577 Cattaneo, A. and Steel, R.J., 2003. Transgressive deposits: a review of their variability. Earth-

578 Science Reviews, 62, pp.187-228.

579 Brown, A.R., 2011. Interpretation of three-dimensional seismic data. Society of Exploration

580 Geophysicists and American Association of Petroleum Geologists, pp. 7.

27

581 Cawthra, H.C., Uken, R. and Ovechkina, M.N., 2012. New insights into the geological

582 evolution of the Durban Bluff and adjacent Blood Reef, South Africa. South

African Journal

583 of Geology, 115, pp. 291-308.

584 Cooper, J.A.G. 1993. Sedimentation in a river-dominated estuary.

Sedimentology, 40, pp. 979-

5851017.

586 Cooper, J.A.G. 1994. Sedimentary processes in the river-dominated Mvoti estuary, South

587 Africa. Geomorphology, 9, pp. 271-300.

588 Cooper, J.A.G., 2001. Geomorphological variability among microtidal estuaries from the

589 wave-dominated South African coast. Geomorphology, 40, pp.99-122.

590 Cooper, J.A.G. and Lemckert, C., 2012. Extreme sea-level rise and adaptation options for

591 coastal resort cities: A qualitative assessment from the Gold Coast, Australia. Ocean \& coastal 
592 management, 64, pp.1-14.

593 Cooper, J.A.G., Smith, A.M. and Green, A.N., 2013. Backbeach deflation aprons: morphology

594 and sedimentology. Journal of Sedimentary Research, 83, pp.395-405.

595 Cooper, J.A.G. and Green, A.N., 2016. Geomorphology and preservation potential of coastal

596 and submerged aeolianite: examples from KwaZulu-Natal, South Africa.

Geomorphology,

597 271, pp.1-12.

598 Cooper, J.A.G., Green, A.N. and Loureiro, C. 2018a. Geological constraints on mesoscale

599 coastal barrier behaviour. Global and Planetary Change, 168, 15-34

600 Cooper, J.A.G., Green, A.N. and Compton, J.S., 2018b. Sea-level change in southern Africa

601 since the Last Glacial Maximum. Quaternary Science Reviews, 201, pp.303318.

602 Davis Jr, R.A. and Clifton, H.E., 1987. Sea-level change and the preservation potential of

603 wave-dominated and tide-dominated coastal sequences. In: Nummedal, D., Pilkey, O.H.,

28

604 Howard, J.D., and Price, W. A., eds., Sea-Level Fluctuation and Coastal Evolution. SEPM, 605 Special Publication, 41, pp. 167-178

606 De Lecea, A.M., Green, A.N., Strachan, K.L., Cooper, J.A.G. and Wiles, E.A., 2017. Stepped

607 Holocene sea-level rise and its influence on sedimentation in a large marine embayment:

608 Maputo Bay, Mozambique. Estuarine, Coastal and Shelf Science, 193, pp.2536.

609 Fairbanks, R.G., 1989. A 17,000-year glacio-eustatic sea level record: influence of glacial

610 melting rates on the Younger Dryas event and deep-ocean circulation. Nature, 342, pp.637. 
611 Flemming, B.W., 1980. Sand transport and bedform patterns on the continental shelf between

612 Durban and Port Elizabeth (southeast African continental margin).

Sedimentary Geology, 26, 613 pp.179-205.

614 Flemming, B.W. and Davis Jr, R.A., 1994. Holocene evolution, morphodynamics and

615 sedimentology of the Spiekeroog barrier island system (southern North Sea). Senckenbergiana

616 maritima. Frankfurt/Main, 24, pp.117-155.

617 Flemming, B.W., 2000. On the dimensional adjustment of subaqueous dunes in response to

618 changing flow conditions: a conceptual process model, in: Trentesaux, A. et al. (Ed.) Marine

619 Sandwave Dynamics, International Workshop, March 23-24, 2000, University of Lille 1,

620 France. Proceedings.

621 Folk, R.L. and Ward, W.C., 1957. Brazos River bar [Texas]; a study in the significance of grain

622 size parameters. Journal of Sedimentary Research, 27, pp.3-26.

623 Gardner, J.V., Calder, B.R., Clarke, J.H., Mayer, L.A., Elston, G. and Rzhanov, Y., 2007.

624 Drowned shelf-edge deltas, barrier islands and related features along the outer continental shelf

625 north of the head of De Soto Canyon, NE Gulf of Mexico. Geomorphology, 89, pp.370-390.

29

626 Green, A.N. and Uken, R., 2005. First observations of sea-level indicators related to glacial

627 maxima at Sodwana Bay, northern KwaZulu-Natal: Research in action. South African Journal

628 of Science, 101, pp.236-238.

629 Green, A.N., 2009. Palaeo-drainage, incised valley fills and transgressive systems tract 
630 sedimentation of the northern KwaZulu-Natal continental shelf, South Africa, SW Indian

631 Ocean. Marine Geology, 263, pp.46-63.

632 Green, A., 2011. Submarine canyons associated with alternating sediment starvation and shelf-

633 edge wedge development: Northern KwaZulu-Natal continental margin, South Africa. Marine

634 Geology, 284, pp.114-126.

635 Green, A. and Garlick, G.L., 2011. A sequence stratigraphic framework for a narrow, current-

636 swept continental shelf: The Durban Bight, central KwaZulu-Natal, South Africa. Journal of

637 African Earth Sciences, 60, pp.303-314.

638 Green, A., Leuci, R., Thackeray, Z. and Vella, G., 2012. Number One Reef: An overstepped

639 segmented lagoon complex on the KwaZulu-Natal continental shelf. South African Journal of

640 Science, 108, pp.113-118.

641 Green, A.N., Cooper, J.A.G., Leuci, R. and Thackeray, Z., 2013a. Formation and preservation

642 of an overstepped segmented lagoon complex on a high-energy continental shelf.

643 Sedimentology, 60, pp.1755-1768.

644 Green, A.N., Dladla, N. and Garlick, G.L., 2013b. Spatial and temporal variations in incised

645 valley systems from the Durban continental shelf, KwaZulu-Natal, South Africa. Marine

646 Geology, 335, pp.148-161.

647 Green, A.N., Cooper, J.A.G. and Salzmann, L., 2014. Geomorphic and stratigraphic signals of

648 postglacial meltwater pulses on continental shelves. Geology, 42, pp.151-154. 30

649 Green, A.N. and MacKay, C.F., 2016. Unconsolidated sediment distribution patterns in the 
650 KwaZulu-Natal Bight, South Africa: the role of wave ravinement in separating relict versus

651 active sediment populations. African Journal of Marine Science, 38(sup1), pp.S65-S74.

652 Green, A.N., Cooper, J.A.G. and Salzmann, L., 2018. The role of shelf morphology and

653 antecedent setting in the preservation of palaeo-shoreline (beachrock and aeolianite)

654 sequences: the SE African shelf. Geo-Marine Letters, 38, pp.5-18.

655 Gibbons, S.J.A. and Nicholls, R.J., 2006. Island abandonment and sea-level rise: An historical

656 analog from the Chesapeake Bay, USA. Global Environmental Change, 16, pp.40-47.

657 Harris, M.S., Sautter, L.R., Johnson, K.L., Luciano, K.E., Sedberry, G.R., Wright, E.E. and

658 Siuda, A.N., 2013. Continental shelf landscapes of the southeastern United

States since the last

659 interglacial. Geomorphology, 203, pp.6-24.

660 Hijma, M.P. and Cohen, K.M., 2010. Timing and magnitude of the sea-level jump preluding

661 the 8200 yr event. Geology, 38, pp.275-278.

662 Jackson, D.W.T., Cooper, J.A.G. and Green, A.N., 2014. A preliminary classification of coastal

663 sand dunes of KwaZulu-Natal. Journal of Coastal Research, 70, pp.718-722. 664 Landsberg, S.Y., 1956. The orientation of dunes in Britain and Denmark in relation to wind.

665 The Geographical Journal, 122, pp.176-189.

666 Liu, J.P. and Milliman, J.D., 2004. Reconsidering melt-water pulses 1A and 1B: global impacts

667 of rapid sea-level rise. Journal of Ocean University of China, 3, pp.183-190. 668 Locker, S.D., Hine, A.C., Tedesco, L.P. and Shinn, E.A., 1996. Magnitude and timing of 669 episodic sea-level rise during the last deglaciation. Geology, 24, pp.827-830. 
670 Martin, A.K. and Flemming, B.W., 1986. The Holocene shelf sediment wedge off the south

671 and east coast of South Africa. Shelf Sands and Sandstones - Memoir 11, pp.27-44.

31

672 Martin, A.K. and Flemming, B.W., 1987. Aeolianitesof the South-African coastal zone and

673 continental shelf as sea-level indicators. South African Journal of Science, 83, pp. 507-508.

674 Martin, A.K., and Flemming, B.W., 1988. Physiography, structure and geological evolution of

675 the Natal continental shelf. In Coastal Ocean Studies off Natal, South Africa. Schumann, E. H.

676 (Ed.). Berlin; Springer: Lecture Notes on Coastal and Estuarine Studies, 26, p.p. 11-46.

677 Martin, A.K. and Flemming, B.W., 1992. Physiography, Structure Add Geological Evolution

678 of The Natal Continental Shelf. Coastal Ocean Studies off Natal, South Africa, pp.11-46.

679 Maselli, V., Hutton, E.W., Kettner, A.J., Syvitski, J.P. and Trincardi, F., 2011. High-frequency

680 sea level and sediment supply fluctuations during Termination I: an integrated sequence-

681 stratigraphy and modeling approach from the Adriatic Sea (Central Mediterranean). Marine

682 Geology, 287, pp.54-70.

683 Maboya, M.L., Meadows, M.E., Reimer, P.J., Backeberg, B.C. and Haberzettl, T., 2017. Late

684 Holocene marine radiocarbon reservoir correction for the south and east coast of South Africa.

685 Mellett, C.L., Hodgson, D.M., Lang, A., Mauz, B., Selby, I. and Plater, A.J., 2012. Preservation

686 of a drowned gravel barrier complex: A landscape evolution study from the north-eastern

687 English Channel. Marine Geology, 315, pp.115-131. 
688 Mellett, C.L. and Plater, A.J., 2018. Drowned barriers as archives of coastalresponse to sea-

689 level rise. In Barrier Dynamics and Response to Changing Climate. Springer, Cham., pp. 57-

69089.

691 Moes H, Rossouw M (2008) Considerations for the utilization of wave power around South

692 Africa. In: van Niekerk W (ed) Abstracts Workshop Ocean energy, 21 February 2008, Spier

693 Conference Centre. Centre for Renewable and Sustainable Energy Studies, University of

694 Stellenbosch, Stellenbosch. Nordfjord, S., Goff, J.A., Austin, J.A. and Gulick, S.P.S., 2006.

32

695 Seismic facies of incised-valley fills, New Jersey continental shelf: implications for erosion

696 and preservation processes acting during latest Pleistocene-Holocene transgression. Journal of

697 Sedimentary Research, 76, pp.1284-1303.

698 Nummedal, D., Swift, D.J.P., 1987. Transgressive stratigraphy at sequencebounding

699 unconformities: some principles derived from Holocene and Cretaceous examples. In:

700 Nummedal, D., Pilkey, O.H., Howard, J.D. (Eds.), Sea-Level Fluctuation and Coastal

701 Evolution. SEPM Special Publication, vol. 41, pp. 241-260..

702 Oestmo, S., Schoville, B.J., Wilkins, J. and Marean, C.W., 2014. A middle stone age

703 paleoscape near the pinnacle point caves, Vleesbaai, South Africa.

Quaternary International,

704 350, pp.147-168.

705 Payenberg, T.H.D., Boyd, R., Beaudoin, J., Ruming, K., Davies, S., Roberts, J., Lang, S.C.,

706 2006. The filling of an incised valley by shelf dunes - an example from Hervey Bay, East Coast 
707 of Australia. In: Dalrymple, R.W., Leckie, D.A., Tillman, R.W. (Eds.), Incised Valleys in Time

708 and Space. SEPM Special Publication, 85, pp. 87-98.

709 Peltier, W.R. and Fairbanks, R.G., 2006. Global glacial ice volume and Last Glacial Maximum

710 duration from an extended Barbados sea level record. Quaternary Science Reviews, 25,

711 pp.3322-3337.

712 Pretorius, L., Green, A. and Cooper, A., 2016. Submerged shoreline preservation and

713 ravinement during rapid postglacial sea-level rise and subsequent "slowstand". Bulletin, 128,

714 pp.1059-1069.

715 Pretorius, L., Green, A.N. and Cooper, J.A., 2018. Submerged beachrock preservation in the 716 context of wave ravinement. Geo-Marine Letters, 38, pp.19-32. 33

717 Ramsey, C.B., 2001. Development of the radiocarbon calibration program. Radiocarbon, 718 43(2A), pp.355-363.

719 Reimer, P.J., Bard, E., Bayliss, A., Beck, J.W., Blackwell, P.G., Ramsey, C.B., Buck, C.E., 720 Cheng, H., Edwards, R.L., Friedrich, M. and Grootes, P.M., 2013. IntCal13 and Marine13

721 radiocarbon age calibration curves $0-50,000$ years cal BP. Radiocarbon, 55, pp.1869-1887.

722 Salzmann, L., Green, A. and Cooper, J.A.G., 2013. Submerged barrier shoreline sequences on

723 a high energy, steep and narrow shelf. Marine Geology, 346, pp.366-374.

724 Sanders, J.E. and Kumar, N., 1975. Evidence of shoreface retreat and in-place "drowning"

725 during Holocene submergence of barriers, shelf off Fire Island, New York. Geological Society

726 of America Bulletin, 86, pp.65-76. 
727 Saito, Y., 2001. Deltas in Southeast and East Asia: their evolution and current problems. In

728 Proceedings of the APN/SURVAS/LOICZ joint conference on coastal impacts of climate

729 change and adaptation in the Asia-Pacific Region, pp. 185-191.

730 Shepard, F.P., 1963. Submarine Geology, 2 ed. Harper and Row, New York, NY, pp. 557.

731 Storms, J.E., Weltje, G.J., Terra, G.J., Cattaneo, A. and Trincardi, F., 2008.

Coastal dynamics

732 under conditions of rapid sea-level rise: Late Pleistocene to Early Holocene evolution of

733 barrier-lagoon systems on the northern Adriatic shelf (Italy). Quaternary Science Reviews, 27,

734 pp.1107-1123.

735 Swift, D.J., 1968. Coastal erosion and transgressive stratigraphy. The Journal of Geology, 76,

736 pp.444-456.

737 Swift, D.J., Niederoda, A.W., Vincent, C.E. and Hopkins, T.S., 1985. Barrier island evolution, 738 middle Atlantic shelf, USA Part I: Shoreface dynamics. Marine Geology, 63, pp.331-361.

34

739 Thanh, T.D., Saito, Y., Van Huy, D., Nguyen, V.L., Ta, T.K.O. and Tateishi, M., 2004.

740 Regimes of human and climate impacts on coastal changes in Vietnam.

Regional

741 Environmental Change, 4, pp.49-62.

742 Thomas, R.J., Armstrong, R.A. and Eglington, B.M., 2003. Geochronology of the Sikombe

743 Granite, Transkei, Natal Metamorphic Province, South Africa. South African Journal of

744 Geology, 106(4), pp.403-408.

745 Trincardi, F. and Field, M.E., 1991. Geometry, lateral variation, and preservation of 
746 downlapping regressive shelf deposits; eastern Tyrrhenian Sea margin, Italy. Journal of

747 Sedimentary Research, 61, pp.775-790.

748 Trincardi, F., Correggiari, A. and Roveri, M., 1994. Late Quaternary

transgressive erosion and

749 deposition in a modern epicontinental shelf: the Adriatic semienclosed basin.

Geo-marine

750 letters, 14, pp.41-51.

751 Weber, N., Chaumillon, E., Tesson, M. and Garlan, T., 2004. Architecture and morphology of

752 the outer segment of a mixed tide and wave-dominated-incised valley, revealed by $\mathrm{HR}$ seismic

753 reflection profiling: the paleo-Charente River, France. Marine Geology, 207, pp.17-38.

754 Yokoyama, Y., Esat, T.M., Thompson, W.G., Thomas, A.L., Webster, J.M., Miyairi, $Y$., 755 Sawada, C., Aze, T., Matsuzaki, H., Okuno, J.I. and Fallon, S., 2018. Rapid glaciation and a 756 two-step sea level plunge into the Last Glacial Maximum. Nature, pp. 559, 603.

757 Zabel, M., (2016). Climate Archives in Coastal Waters of Southern Africa (Meteor Berichte), 758 Cruise No. M123.

759 Zaitlin, B.A., Dalrymple, R.W. and Boyd, R., 1994. The stratigraphic organisation of incised 760 valley systems associated with relative sea-level change. In: Incised Valley Systems: origin

35

761 and Sedimentary Sequences. Eds R.W. Dalrymple, R.J. Boyd and B.A. Zaitlin, SEPM Spec.,

762 51, pp.45-60.

\section{Figure Captions}

764 Fig. 1 Locality map illustrating the extent of the bathymetric and seismic data collected. The 
765 study area is situated seaward of the Umzimkulu River mouth and focuses on the large seafloor

766 shoal of the Protea Banks. Grey lines indicate boomer seismic profiles and blue lines indicate

767 PARASOUND profiles. The red circle indicates the location of corescore GeoB20622-2.

768 Fig. 2 Interpreted shore-perpendicular seismic profile showing underlying Cretaceous strata

769 and capping high amplitude reflector (Surface 2) and prominent ridges of Unit 5 at $-60 \mathrm{~m}$.

770 Expanded areas show: a) Rugged Unit 5, capped by erosional Surface 3. b) An incision filled

771 by Unit 4 showing chaotic, discontinuous reflectors. c) A complete incised valley-fill

772 succession comprising Sub-units 4.1, 4.2 and 4.3, capped by an erosional reflector and overlain

773 by Unit 6.3. S1 - Surface 1 (Sequence Boundary), S2 - Surface 2 (Maximum Flooding Surface)

774 and S3 - (Sequence Boundary).

775 Fig. 3 Interpreted shore-perpendicular seismic profile. Note the lack of sediment cover above

776 the acoustic basement. Expanded areas show: a) Acoustically opaque Unit 5 onlapped both

777 landward and seaward by Sub-unitUnit 6.2, capped by a thin drape of SubunitUnit 6.3. b) A

778 complete incised valley-fill succession comprising Sub-units 4.1, 4.2 and 4.3, capped by an

779 erosional reflector and overlain by Unit 6.3

780 Fig. 4 Interpreted shore-perpendicular seismic profile showing incised valley systems on the

781 inner-shelf, together with a ridge of Unit 5 at a depth of $100 \mathrm{~m}$ on the outershelf. Expanded

782 areas show: a) an incised valley fill succession comprising Sub-unitUnit 4.1, truncated by an 
783 erosional surface and overlain by sub-parallel to chaotic reflectors of SubunitUnit 6.2. Core

784 location is indicated by the red line which intersects Sub-unitUnit 6.3 only. b)

a PARASOUND

36

785 shore-parallel interpreted section showing an alternative view to Fig. 4a3a with marked core

786 location (red line) and a bathymetric depression associated with an underfilled incised valley

787 and core location (red dot). c) A complete incised valley-fill succession comprising Sub-units

788 4.1, 4.2 and 4.3, capped by an erosional reflector and overlain by Unit 6.3. Note that Unit 4.3

789 is truncated by Surface 4, which merges with Surfaces 2 and 3 to form a composite erosional

790 surface $2 / 3 / 4$

791 Fig 5 Interpreted shore-perpendicular PARASOUND profile showing the detailed internal

792 configuration of the upper seismic units. The expanded areas show: a) Unit 3 resting within a

793 depression created by Unit 2 and capped by an erosion surface. Unit 6.1 shows sub-parallel to

794 chaotic reflectors draping the underlying erosional surface. Unit 6.3 drapes over Unit 6.1 with

795 continuous, semi-parallel reflectors. b) Unit 5, onlapped by sub-units 6.2 and 6.3. Note the

796 seaward-oblique prograding foresets in Sub-unitUnit 6.2. c) Unit 5 superimposed onto

797 Cretaceous deposits, capped by an erosional surface and onlapped by SubunitUnit 6.2

798 Fig 6 Interpreted shore-parallel boomer seismic profile showing the innershelf sediment. The

799 expanded areas show: a) Cretaceous basement truncated by an erosional reflector and overlain 
800 by the sub-parallel, horizontal reflector package of Sub-unitUnit 6.1. b) Incised valleys filled

801 by the homogenous, discontinuous and chaotic seismic Unit 4. Sub-unitUnit 6.1 drapes Unit 4.

802 Fig 7 Interpreted shore-perpendicular boomer seismic profile showing planation surface

803 truncating Cretaceous strata, superimposed in the outer-shelf region by ridge features. The

804 expanded areas show: a) Unit 6.2 resting within depressions of Surface 5.

Sub-unitUnit 6.3

805 onlaps both Sub-unitUnit 6.2 and Unit 5. b) Cropping out foresets of Unit 2.1 draped by a thin

806 veneer of Sub-unitUnit 6.1 in the inner-shelf region.

807 Fig 8 Bathymetry of the study area showing the main morphological features of the continental

808 shelf. The insets show: a) Parabolic ridges at $\sim 60 \mathrm{~m}$ depth. b) Shore-parallel ridge features. c)

37

809 A pronounced ridge feature with depressions on the seaward and landward side. Not the 'break'

810 within the feature. d) Plan and cross-sectional view of wide, U-shaped depressions on seafloor.

811 e) Plan and cross-sectional view of a sinuous sea-floor depression.

812 Fig 9 Depth structure map of the LGM subaerial unconformity (Surface 2), depicting the trend

813 of the drainage network from the pre-LGM regression, in relation to the Umzimkulu river and

814 antecedent topographical highs and lows. Note the correlation with the small ridges of Unit 5

815 at the shelf edge, together with sinuous seafloor depressions. Vessel lines are superimposed on

816 Surface 2 as black lines.

817 Fig 10 IllustrationGraphic log of the sampled core corresponding to Sub-unit 6.3GeoB20622- 
818 2. The core is dominated by very coarse to coarse, quartz sand interspersed with bioclastic

819 material. The lower section of the core shows a crude upward fining trend in grain-size and is

820 capped with flat-lying quartz pebble layers. The upper most pebble horizon yields an age of

$8211275 \pm 30$ Cal. yrs B.P.1191 - 1263 cal yr BP (68\% range). The entire core comprises layers

822 of Unit 6.3 separated by an internal master bedding plane (IMBP) indicated by the dashed line.

823 Inset a) shows a high-resolution photograph of the pebble horizons in-situ. b) and c) Show

824 rounded oblate quartz pebble obtained from the core. d) Shows a rounded, oblate beachrock

825 pebble. Note the similarity in size of the pebbles.

826 Fig 11 Relative sea- level curve for the east coast of South Africa from the 12 20000 Cal yr

827 B.P. to present day (after Cooper et al., 20182018b). Grey shading marks periods of sea- level

828 events pertaining to this study. After Cooper et al. (2018).

829 Fig 12 Interpreted shore perpendicular seismic profiles of incised valley fills from different

830 zones of the shelf. a) The inner-shelf comprising fluvial, central basin and estuarine barrier

831 deposits capped by shelf sand. b) Mid-shelf comprising a higher ratio of central basin deposits

832 to fluvial deposits, topped by estuarine barrier and shelf sand deposits. c) Outer-shelf

38

833 comprising fluvial sediment overlain by shelf/subaqueous dune sediment. The locations of

834 these valleys are indicated on Figure 1.

835

836 Table 1. Summary of seismic stratigraphic units, separating stratal surfaces and interpreted 
837 depositional environments.

838 Table 2. Summary of core sediment facies and faunal descriptions relative to seismic

839 stratigraphy. 